\title{
Deskripsi Penalaran Siswa dalam Pemecahan Masalah Matematika pada Pokok Bahasan Barisan dan Deret Ditinjau dari Kemampan Awal
}

\author{
Irma Sulistiawati ${ }^{1, \mathrm{a})}$, Nurdin Arsyad ${ }^{1}$, Ilham Minggi ${ }^{1}$ \\ ${ }^{1}$ Jurusan Matematika, Fakultas MIPA, Universitas Negeri Makassar \\ a) irmasulistiawati96@gmail.com
}

\begin{abstract}
Abstrak. Penelitian ini bertujuan untuk mendeskripsikan penalaran siswa dalam pemecahan masalah matematika pada pokok bahasan barisan dan deret yang ditinjau dari kemampuan awal. Jenis penelitian ini adalah kualitatif deskriptif. Dengan menggunakan teknik purposive sampling, maka, dipilih subjek penelitian sebanyak 2 siswa kelas XI MIPA salah satu SMA di Makassar. Adapun teknik pengumpulan data menggunakan metode tes dan wawancara kemudian melalui tiga tahapan analisis data yaitu reduksi data, penyajian data, dan penarikan kesimpulan. Hasil penelitian diperoleh bahwa proses penalaran siswa yang berkemampuan tinggi yaitu mengaitkan konsep dan pengetahuan yang dimilikinya, mengumpulkan bukti dengan menyebutkan hal-hal yang diketahui dan ditanyakan, mengaitkan rumus yang sudah dimiliki dengan masalah yang dihadapi, mengidentifikasi konsep yang digunakan untuk memecahkan masalah, mengungkapkan alasan dalam menjelaskan langkah-langkah dalam melaksanakan pemecahan masalah. Dan menarik kesimpulan menjelaskan konsep yang digunakan dari soal. Sedangkan proses penalaran siswa berkemapuan rendah yaitu menyebutkan hal-hal yang diketahui dan ditanyakan serta siswa tidak dapat membuat kesimpulan apapun setelah menyelesaikan soal. Hal ini disebabkan karena belum memahami soal sepenuhnya, siswa tidak terbiasa mengoreksi kembali jawaban yang diperoleh, dan siswa tidak terbiasa menuliskan kesimpulan akhir
\end{abstract}

Kata kunci: penalaran, pemecahan masalah, barisan dan deret, kemampuan awal

\begin{abstract}
This study aims to describe students' reasoning in mathematical problem solving on the topic sequences and series viewed by prior knowledge. This type of research is descriptive qualitative. By using purposive sampling technique, then, the research subjects were selected as many as 2 students of class XI MIPA, one of the high schools in Makassar. The data collection technique uses test methods and interviews then through three stages of data analysis, namely data reduction, data display, and drawing conclusion. The results showed that the reasoning process of high-ability students was to associate the concepts and knowledge they had, gather evidence by mentioning things that were known and asked, linking the formulas that were already owned with the problems faced, identifying concepts used to solve problems, revealing reasons in explaining the steps in carrying out problem solving. And drawing conclusions explains the concepts used from the problem. While the reasoning process of low-ability students is to mention things that are known and asked and students cannot make any conclusions after solving the problem. This is because students have not fully understood the problem, students are not used to correcting the answers obtained, and students are not used to writing final conclusions
\end{abstract}

Keywords: reasoning, problem solving, sequence and sequence, prior knowledge 


\section{PENDAHULUAN}

Pemecahan masalah adalah usaha dalam mencari jalan keluar dari suatu kesulitan untuk mencapai suatu tujuan yang tidak dapat segera dicapai (Polya, 1973). Pemecahan masalah merupakan bagian yang sangat penting dari matematika. Krulik dan Rudnick (1995) mengemukakan bahwa pemecahan masalah merupakan proses individu menggunakan pengetahuan, keterampilan, dan pemahaman yang telah diperoleh untuk menyelesaikan masalah pada situasi yang tidak dikenalnya. Salah satu tujuan pembelajaran matematika adalah agar siswa memiliki kemampuan pemecahan masalah. Kemampuan pemecahan masalah yang dimaksud proses yang dilakukan seseorang untuk mendapatkan solusi dalam menyelesaikan soal yang didapatkannya yang tidak biasa diselesaikan secara umum (masalah non rutin). Tujuan tersebut menempatkan pemecahan masalah menjadi bagian yang penting dari kurikulum matematika.

Dalam pemecahan masalah ada komponen kognitif yang harus dimiliki oleh siswa, yaitu pemahaman terhadap masalah dan penalaran. Penalaran merupakan suatu proses berpikir dalam menarik sesuatu kesimpulan yang berupa pengetahuan (Suriasumantri, 2010). Penalaran adalah alat untuk memahami matematika dan pemahaman matematik itu digunakan untuk menyelesaikan masalah (Dominowski \& Dallop, 1995). Dengan kata lain, penalaran adalah bagian tertentu dari pekerjaan memecahkan masalah

Meskipun penalaran merupakan aspek yang penting dalam pemecahan masalah, tetapi hal tersebut tidak sejalan dengan kemampuan penalaran matematis yang telah dicapai siswa saat ini. Kelemahan penalaran dalam pemecahan masalah siswa dapat dilihat dari hasil tes yang dilakukan oleh dua studi internasional. Dua studi internasional tersebut adalah PISA dan TIMSS. Laporan PISA (2015) skor matematika siswa Indonesia berada pada posisi 64 dari 72 negara dengan rata-rata skor 386, sementara ratarata skor internasional adalah 494. Pada laporan TIMSS (2015) siswa Indonesia berada pada posisi 45 dari 50 negara dengan rata-rata skor 386. Ini berarti kemampuan pemecahan masalah siswa indonesia berdasarkan hasil dari PISA dan TIMSS masih rendah dibandingkan siswa dari negara lain.

Salah satu faktor yang mempengaruhi penalaran siswa dalam pemecahan masalah adalah kemampuan awal siswa. Setiap siswa masing-masing memiliki kemampuan awal yang berbedabeda. Kemampuan awal merupakan kemampuan siswa dalam menyelesaikan masalahmasalah rutin yang telah dipelajari sebelumnya.

Beberapa temuan penelitian yang relevan tentang penalaran matematika siswa dalam pemecahan masalah telah dilakukan (Basri, 2015; Dahlia, 2008; Priatna, 2003; Nasution, 2011). Basir (2015) menganalisis kemampuan penalaran siswa dalam pemecahan masalah ditinjau dari gaya kognitif. Selanjutnya, Dahlia (2008) meneliti tentang pembelajaran matematika dengan menggunakan model treffinger dalam upaya meningkatkan kemampuan penalaran adaptif siswa.

Penelitian ini mengkaji tentang penalaran siswa dalam pemecahan masalah ditinjau dari kemampuan awal. Tujuan penelitian ini untuk mengetahui penalaran siswa dalam pemecahan masalah ditinjau dari kemampuan awal. Subjek penelitian ini adalah siswa kelas XI SMA. Materi yang diberikan adalah Barisan dan Deret.

Barisan dan Deret adalah materi yang diajarkan pada kelas XI. Dipilihnya materi Barisan dan Deret dalam penelitian ini dikarenakan pada materi ini terdapat berbagai persoalan yang berupa pemecahan masalah sehingga dapat membantu peneliti dalam menganalisis penalaran siswa dalam pemecahan masalah matematika. Pada materi Barisan dan Deret, banyak soal yang dapat dibentuk dalam soal-soal non rutin, yakni suatu permasalahan matematika yang tidak biasa dan tidak ada standar yang pasti untuk menyelesaikannya. Oleh karena itu, penyelesaian soal non rutin yang berkaitan dengan Barisan dan Deret diselesaikan dengan cara yang tidak 
biasa dilakukan. Hal tersebut berarti dibutuhkan penalaran matematis dalam pemecahan soalsoal non rutin.

\section{KAJIAN PUSTAKA}

Penalaran merupakan suatu kegiatan, suatu proses atau aktivitas berpikir untuk menarik kesimpulan atau membuat suatu pernyataan baru yang benar berdasar pada beberapa pernyataan yang kebenarannya telah diasumsikan sebelumnya (Shadiq, 2004). Keraf (2007) mendefinisikan penalaran sebagai suatu proses berpikir yang berusaha menghubungkan faktafakta yang diketahui menuju pada suatu kesimpulan. NCTM (Sherly, 2016) secara umum terdapat beberapa tahapan dalam penalaran matematis yaitu: (a) menganalisis masalah, (b) menerapkan strategi, (c) mencari dan menggunakan hubungan antara domain matematika yang berbeda, konteks yang berbeda, dan representasi berbeda, (d) merefleksikan solusi pada suatu masalah. Hampir sejalan dengan Departemen Pendidikan Nasional dalam Peraturan Dirjen Dikdasmen No 506/C/PP/2004 (Wardhani, 2008) memberikan cakupan aktivitas penalaran sekaligus melengkapi penjelasan cakupan kemampuan penalaran matematis adalah:

Mengajukan dugaan (conjectures)

Mengajukan dugaan merupakan proses siswa dalam merumuskan berbagai kemungkinan pemecahan sesuai dengan pengetahuan yang dimilikinya.

- Melakukan manipulasi matematika

Manipulasi matematika merupakan proses siswa dalam mengerjakan atau menyelesaikan suatu permasalahan dengan menggunakan cara sehingga tercapai tujuan yang dikehendaki

- Menarik kesimpulan, menyusun bukti, memberikan alasan atau bukti terhadap beberapa solusi.

Proses siswa dalam menarik kesimpulan, menyusun bukti, memberikan alasan atau bukti terhadap kebenaran solusi apabila siswa menunjukkan lewat penyelidikan

- Menarik kesimpulan

Menarik kesimpulan dari pernyataan merupakan proses berpikir yang memberdayakan pengetahuannya sedemikian rupa untuk menghasilkan sebuah pemikiran.

- Memeriksa kesahihan suatu argument

Memeriksa kesahihan suatu argumen merupakan Proses penalaran yang menghendaki siswa agar menyelidiki tentang kebenaran dari suatu pernyataan yang ada.

- Menemukan pola atau sifat dari gejala matematis untuk membuat generalisasi.

Proses siswa dalam menemukan pola atau cara dari suatu pernyataan yang ada sehingga dapat mengembangkannya ke dalam kalimat matematika.

Selanjutnya mengenai pentingnya peran penalaran matematis dalam matematika dikemukakan oleh Loong, Vale, Bragg dan Herbert (2013) yang menyatakan bahwa penalaran matematis adalah kemampuan yang dijadikan pondasi dalam berpikir matematis. Polya (1973) juga menambahkan bahwa kemampuan penalaran berperan penting dalam kesuksesan belajar matematika. Salah satu peran penting penalaran matematis dalam matematika adalah untuk mengembangkan keterampilan siswa dalam memecahkan masalah. Dengan kebiasaan bernalar secara matematis yang baik, siswa akan mampu memahami dan menggunakan apa yang telah mereka pelajari di sekolah untuk menyelesaikan masalah secara efektif.

Indikator penalaran matematis dalam memecahkan masalah yang digunakan dalam penelitian ini dapat dilihat pada Tabel 1.

Ada beberapa studi yang telah dilakukan peneliti berkaitan dengan kemampuan penalaran matematik siswa. Basir (2015) menganalisis kemampuan penalaran siswa dalam pemecahan masalah ditinjau dari gaya kognitif. Hasil penelitian menunjukkan bahwa subjek bergaya kognitif field independent menguasai lebih tiga dari tujuh indikator kemampuan penalaran matematis. Sementara subjek bergaya kognitif field dependent hanya menguasai kurang empat 
dari tujuh indikator penelaran matematis. Selain itu, Dahlia (2008) meneliti tentang kemampuan penalaran adaptif siswa. Ia menjelaskan bahwa pada saat siswa diberikan soal yang berbeda dari biasanya dan setiap siswa harus memberikan alasan yang logis dan tepat terhadap semua jawaban yang mereka pilih, kebanyakan siswa mengeluh dan kesulitan menyelesaikannya.

TABEL 1. Indikator Penalaran Matematika

\begin{tabular}{|c|c|}
\hline Indikator Penalaran & Keterangan \\
\hline $\begin{array}{l}\text { Mengajukan dugaan } \\
\text { (konjektur) }\end{array}$ & $\begin{array}{l}\text { - Siswa dapat memperkirakan jawaban tanpa } \\
\text { menggunakan rumus } \\
\text { - Siswa dapat menggunakan pola/cara dan } \\
\text { hubungan untuk menganalisis situasi yang } \\
\text { dihadapi dalam proses pemecahan masalah }\end{array}$ \\
\hline $\begin{array}{l}\text { Memberikan alasan atau } \\
\text { bukti terhadap beberapa } \\
\text { solusi }\end{array}$ & $\begin{array}{l}\text { - Mengumpulkan bukti dari masalah } \\
\text { - Siswa menjelaskan secara rinci proses } \\
\text { solusi yang dilakukan dan memberikan } \\
\text { bukti terhadap hasil yang diperoleh }\end{array}$ \\
\hline $\begin{array}{l}\text { Melakukan manipulasi } \\
\text { matematika }\end{array}$ & $\begin{array}{l}\text { - Siswa dapat melakukan manipulasi } \\
\text { matematika dalam menyelesaikan masalah }\end{array}$ \\
\hline Menarik kesimpulan & $\begin{array}{l}\text { - Dapat menarik kesimpulan dari pemecahan } \\
\text { masalah yang telah dilakukan }\end{array}$ \\
\hline
\end{tabular}

\section{METODE PENELITIAN}

Jenis penelitian ini adalah kualitatif jenis deskriptif. Penelitian ini bertujuan untuk mendeskripsikan penalaran matematika siswa dalam pemecahan masalah. Pokok bahasan dalam penelitian ini adalah barisan dan deret. Dalam pemecahan masalah tersebut akan dilihat bagaimana proses penalaran siswa dibagi kedalam empat indikator penalaran yaitu (I) mengajukan dugaan; (II) memberikan alasan atau bukti; (III) manipulasi matematika dan (IV) menarik kesimpulan.

Subjek terdiri dari 2 siswa, masing-masing 1 siswa yang berkemampuan tinggi dan 1 siswa yang berkemampuan rendah. Kedua siswa tersebut dipilih menggunakan teknik teknik purposive sampling dengan kriteria 1) siswa yang telah mendapatkan pembelajaran materi barisan dan deret; 2) siswa yang telah melaksanakan tes kemampuan awal. Untuk tes kemampuan awal, siswa dibei soal pilihan ganda. Setelah itu, hasil tes tersebut dianalsis kemudian dipilih 2 subjek. Masing-masing 1 subjek dengan jawaban benar paling banyak dan 1 subjek dengan jawaban benar paling sedikit. Adapun hasil tes kemampuan awal kedua subjek dapat dilihat pada Tabel 2.

\begin{tabular}{cc} 
TABEL 2. Hasil Tes Kemampuan Awal Siswa \\
\hline Subjek & Nilai \\
\hline SKT1 & 90 \\
SKR1 & 45
\end{tabular}

Kedua subjek yang telah terpilih kemudian diberikan dua buah soal tes pemecahan masalah SOAL PEMECAHAN MASALAH 1

Jumlah barisan geometri $\mathrm{U}_{1}+\mathrm{U}_{2}+\cdots$, jika $\mathrm{U}_{1}=\mathrm{x}^{-2}, \mathrm{U}_{5}=\mathrm{x}^{2}, \mathrm{U}_{9}=64$. Tentukanlah $\mathrm{U}_{7}$ !

SOAL PEMECAHAN MASALAH 2

Tiga buah bilangan merupakan barisan aritmatika. Bila suku tengahnya dikurangi 5 maka terbentuk suatu barisan geometri dengan rasio sama dengan 2. Tentukan jumlah barisan aritmetika tersebut 
Setelah itu, dilakukan wawancara kemudian di transkrip, kemudian ditarik kesimpulan untuk mendapatkan informasi tentang proses penalaran siswa dalam memecahkan masalah.

\section{HASIL PENELITIAN DAN PEMBAHASAN}

\section{Mengajukan Dugaan (Conjecture)}

SKT menjelaskan dugaan jawaban dengan dengan mencoba-coba berbagai macam cara penyelesaian. Salah satu cara yang digunakan SKT adalah konsep perkalian dan pembagian dalam menyelesaikan masalah. Hal tersebut dapat dilihat pada petikan wawancara Transkrip 1.

\section{TRANSKRIP 1}

P1-03 : Bagaimana anda menduga untuk jawaban no. 1?

SKT-1-W03 : Mungkin bisa dibagi-bagi dua dulu kak. Kan $U_{9}$ nya 64, sedangkan 2 kelipatannya itu 64. Jadi dibagi-bagi dua untuk dapat $U_{1}$ nya.

Transkrip 1 menunjukkan bahwa SKT mencoba melakukan dugaan jawaban dengan menggunakan konsep perkalian dan pembagian. SKT mencari $U_{1}$ dengan membagi terus menerus nilai $\mathrm{U}_{9}$ dengan 2 hingga diperoleh nilai $\mathrm{U}_{1}$.

Adapun SKR tidak dapat membuat dapat dugaan jawaban seperti halnya SKT. Hal tersebut dapat dilihat pada petikan wawancara Transkrip 2.

TRANSKRIP 2

P1-12 : Bisaki duga jawaban ta tanpa menggunakan rumus dek?

SKR-1-W12 : Tidak kak.

Transkrip 2 menunjukkan bahwa SKR tidak dapat membuat dugaan jawaban. SKR tidak memiliki gagasan apapun untuk menduga jawaban.

\section{Memberikan Alasan atau Bukti terhadap beberapa Solusi}

SKT mengumpulkan bukti dengan menuliskan dan menyebutkan hal-hal yang diketahui dan ditanyakan dengan menggunakan bahasanya sendiri. Hal tersebut dapat dilihat pada Gambar 1 dan petikan wawancara Transkrip 3.

$$
\begin{aligned}
& \text { a. Diks } U_{1}=x^{-2} \\
& v_{s}=x^{2} \\
& \text { Dit }=V_{7} \cdots \text { ? }
\end{aligned}
$$

GAMBAR 1. Mengumpulkan bukti

Gambar 1 memperlihatkan bahwa SKT menuliskan hal-hal yang diketahui dan ditanyakan. Dengan menuliskan hal tersebut, SKT mengetahui tahu kemana arah untuk menyelesaikan soal yang diberikan.

\section{TRANSKRIP 3}

P1-01 : Informasi apa yang kita peroleh dek dari soal no. 1, apakah yang

SKT-1-W01 : $\quad$ Diketahui $U_{1}=X^{-2}, U_{5}=X^{2}, U_{9}=64$,yang ditanyakan disini $U_{7}$.

Transkrip 3 menunjukkan bahwa SKT menyebutkan hal-hal yang diketahui dan ditanyakan dengan menggunaan bahasanya sendiri.

Selanjutnya, SKR mengumpulkan bukti dengan menuliskan dan menyebutkan hal-hal yang diketahui dan ditanyakan sambil membaca soal. Hal tersebut dapat dilihat pada Gambar 2 dan petikan wawancara Transkrip 4. 


$$
\begin{aligned}
& u_{1}=x^{-2} \\
& u_{5}=x^{2} \\
& u_{g}=64 .
\end{aligned}
$$

GAMBAR 2. Mengumpulkan bukti

Gambar 2 memperlihatkan SKR mengumpulkan bukti dengan menuliskan hal-hal yang diketahui, akan tetapi tidak menuliskan apa yang ditanyakan.

\section{TRANSKRIP 4}

\section{P1-01 : Pada soal no 1, informasi apa yang anda peroleh?}

SKR1-1-W01: $\quad U_{1}$ nya itu $x^{-2}, U_{5}=x^{2}, U_{9}=64$. ditanyakan $U_{7}$ (sambil membaca soal)

Transkrip 4 menunjukkan bahwa SKR menyebutkan hal-hal yang diketahui dan ditanyakan sambil membaca soal.

\section{Melakukan Manipulasi Matematika}

SKT melakukan manipulasi matematika dengan menggunakan konsep perpangkatan. SKT menggunakan konsep tersebut untuk memudahkannya dalam proses penyelesaian masalah. Hal tersebut dapat dilihat pada Gambar 3.

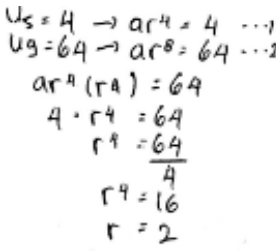

GAMBAR 1. Manipulasi Matematika

Gambar 1 menunjukkan bahwa bahwa SKT menggunakan konsep perpangkatan. Pada baris ke3 SKT memanipulasi $a r^{8}$ menjadi $a r^{4} . r^{4}$. hal tersebut dilakukan untuk memdapatkan nilai $r$.

Adapun SKR tidak melakukan manipulasi apapun pada proses mengerjakan soal. Akan tetapi, SKR hanya menuliskan jawaban berdasarkan apa yang diketahuinya.

\section{Menarik Kesimpulan}

SKT menarik kesimpulan dengan menjelaskan bagaimana mengerjakan soal-soal rutin barisan geometri dengan mudah. SKT juga menjelaskan kembali langkah-langkah penyelesaian dari soal secara singkat dan jelas. Hal tersebut dapat dilhat pada petikan wawancara Transkrip 5.

TRANSKRIP 5

P1-18 : Jadi apa yang bisa anda simpulkan dari ini?

SKT-1-W18: $\quad$ Kalau saya simpulkan toh, untuk mendapatkan $U_{7}$ dari geometri

harus diketahui dua suku, jadi berhubungan sekali karena agar memudahkan untuk mencari barisan geometrika misalnya $a=U_{1}$, kalau rumus mencari $r=\frac{U_{2}}{U_{1}}$, kan 2 mi itu jadi mudahki.

Transkrip 5 memperlihatkan bahwa SKT menarik kesimpulan dengan menjelaskan cara mudah mengerjakan soal-soal barisan geometri. SKT menjelaskan bagaimana cara untuk mendapatkan $\mathrm{U}_{7}$.

Selanjutnya SKR tidak dapat menarik kesimpulan apapun setelah menyelesaikan soal yang diberikan. Hal tersebut dapat dilihat pada petikan wawancara Transkrip 6. 


\section{TRANSKRIP 6}

P2-23 : Apa yang bisa anda simpulkan dari jawaban anda?

SKR1-2-W23: $\quad$ Disoal ini saya sudah lupa kak krena saya tidak mengerti.

Transkrip 6 menunjukkan bahwa SKR tidak dapat menarik kesimpulan apapun dengan alasan SKR sudah lupa cara menyelesaikan soal yang telah diberikan. SKR pun mengakui bahwa ia tidak memahami soal tersebut.

\section{KESIMPULAN}

Proses penalaran matematika siswa berkemampuan tinggi dan rendah sangat berbeda. Siswa berkemampuan tinggi bernalar dengan melakukan teknik coba-coba dengan mengaitkan konsep dari soal yang dimaksud dan pengetahuan yang dimilikinya, mengumpulkan bukti dengan menyebutkan hal-hal yang diketahui dan ditanyakan, menggunakan konsep lain atau pengetahuan yang dimilikinya untuk memudahkannya menyelesaikan masalah, serta membuat kesimpulan dengan menjelaskan konsep yang digunakan dari soal. Sedangkan siswa yang berkemampuan rendah, hanya mengumpulkan bukti dengan menyebutkan hal-hal yang diketahui dan ditanyakan.

Penelitian ini bertujuan untuk mendeskripsikan penalaran siswa dalam pemecahan masalah matematika ditinjau dari kemampuan awal. Penelitian lain yang dapat dilakukan adalah meneliti kembali deskripsi penalaran siswa dalam pemecahan masalah matematika ditinjau dari sudut pandang yang berbeda seperti ditinjau dari gaya kognitif siswa, kebiasaan belajar, gender dll. Hal tersebut dilakukan untuk melihat perbedaan proses penalaran setiap siswa.

\section{DAFTAR PUSTAKA}

Basri, M. A. (2015). Kemampuan Penalaran Siswa dalam Pemecahan Masalah Matematis ditinjau dari Gaya Kognitif. Skripsi FKIP Unisula Semarang. Tidak Diterbitkan

Dahlia, D. (2008) Pembelajaran Matematika dengan Menggunakan Model Treffinger dalam Upaya Meningkatkan Kemampuan Penalaran Adaptif Siswa. Skripsi UPI. Tidak diterbitkan

Dominowski, R. L., Dallob, P. (1995). Insight and problem solving. Cambridge

Keraf, G (2007). Argumentasi dan Narasi. Jakarta: Gramedia

Krulik, S dan Rudnick, J. A. (1995). Problem Solving a Handbook for Elementary School Teachers. Boston: Temple University.

Loong, E, Vale, C, Bragg, L, \& Herbert, S. (2013). Primary School teachers' perceptions of mathematical reasoning. In Mathematics Education: Yesterday, Today and Tomorrow. Melbourne: Merga

Nasution, S (2011). Metode Penelitian Naturalistik Kualitatif. Bandung: Tarsito

Polya, G (1973). How to Solve it.

Priatna, N. (2003). Kemampuan Penalaran MAtematika Siswa Kelas 3 Sekolah Lanjutan Tingkat Pertama Negeri di Kota Bandung. Disertasi pada PPs UPI. Bandung: tidak dipublikasikan.

Shadiq, F. (2004). Pemecahan Masalah, Penalaran, dan Komunikasi. Makalah disampaikan pada Diklat Instruktur/Pengembang Matematika SMP Jenjang Dasar di PPPG Matematika Tanggal 6 s.d. 19 Agustus 2004. Yogyakarta: Depdiknas Dirjendiknas Dasar dan Menengah Pusat Pengembangan Penataran Guru (PPPG) Matematika Yogyakarta. 
Sherly, M.P.Y. 2016. Penalaran Matematis siswa dalam Pemecahan Masalah Aljabar ditinjau dari gaya kognitif Field Dependent-Fiel Independent. Surakarta: Jurnal Ilmiah Pendidikan Matematika. Volume VI. Nomor 2 Tahun 2016. Prodi Magister Pendidikan Matematika, FKIP Universitas Sebelas Maret.

Penulis. (Tanggal, Bulan, dan Tahun Postingan). Judul. Alamat Uniform Resources Locator (URL). Tanggal Diakses.

Sudrajat, A. (5 februari 2013). Pendekatan Saintifik Ilmiah daam Pembelajaran: https://akhmadsudrajat.files.wordpress.com. Diakses tanggal 9 Januari 2018

Suherman, E, Turmudi, Suryadi, D., Herman, T., Suhendra, Prabawonto, S., Nurjanah dan Rohayati, A. (2003). Strategi Pembelajaran Matematika Kontemporer (Edisi Revisi). Jakarta: JICA.

Suriasumantri, J S. (2010). Filsafat Ilmu: Sebuah Pengantar Populer. Jakarta: Sinar Harapan

Syam, I. (15 Agustus 2011). Hubungan Antara Kreatifitas Dengan Hasil Belajar Fisika. http://www.slideshare.net/ismd. Diakses pada 9 Januari 2018

Uno, H B. (2011). Perencanaan pembelajaran. Jakarta: PT. Bumi Aksara.

Wardhani Sri. (2008). Analisis SI dan SKL Mata Pelajaran Matematika SMP/MTS Untuk Optimalisasi Pencapaian Tujuan. Yogyakarta: Pusat Pengembangan dan Pemberdayaan Pendidik dan Tenaga Kependidikan Matematika 